\title{
Diagnosis of toxoplasmosis and typing of Toxoplasma gondii
}

Quan Liu ${ }^{1,2^{*}}$, Ze-Dong Wang ${ }^{2}$, Si-Yang Huang ${ }^{1,3}$ and Xing-Quan Zhu ${ }^{1,3^{*}}$

\begin{abstract}
Toxoplasmosis, caused by the obligate intracellular protozoan Toxoplasma gondii, is an important zoonosis with medical and veterinary importance worldwide. The disease is mainly contracted by ingesting undercooked or raw meat containing viable tissue cysts, or by ingesting food or water contaminated with oocysts. The diagnosis and genetic characterization of $T$. gondii infection is crucial for the surveillance, prevention and control of toxoplasmosis. Traditional approaches for the diagnosis of toxoplasmosis include etiological, immunological and imaging techniques. Diagnosis of toxoplasmosis has been improved by the emergence of molecular technologies to amplify parasite nucleic acids. Among these, polymerase chain reaction (PCR)-based molecular techniques have been useful for the genetic characterization of T. gondii. Serotyping methods based on polymorphic polypeptides have the potential to become the choice for typing $T$. gondii in humans and animals. In this review, we summarize conventional non-DNA-based diagnostic methods, and the DNA-based molecular techniques for the diagnosis and genetic characterization of T. gondii. These techniques have provided foundations for further development of more effective and accurate detection of $T$. gondii infection. These advances will contribute to an improved understanding of the epidemiology, prevention and control of toxoplasmosis.
\end{abstract}

Keywords: Toxoplasma gondii, Toxoplasmosis, Diagnosis, Genetic characterization, Genotyping, Serotyping

\section{Review}

Toxoplasma gondii is a protozoan parasite that infects almost all warm-blooded animals, including humans, and is considered one of the most successful eukaryotic pathogens [1]. Approximately $30 \%$ of human population worldwide is chronically infected with $T$. gondii [2]. Human infections are primarily obtained by ingesting undercooked or raw meat containing viable tissue cysts, or by ingesting food or water contaminated with $T$. gondii oocysts $[3,4]$. Primary infections in adults are mostly asymptomatic, but lymphadenopathy or ocular toxoplasmosis can present in some patients [5]. Severe acute, disseminated toxoplasmosis may occur in immunocompetent individuals when infected with some isolates [6-10].

\footnotetext{
*Correspondence: liuquan1973@hotmail.com; xingquanzhu1@hotmail.com 'State Key Laboratory of Veterinary Etiological Biology, Key Laboratory of Veterinary Parasitology of Gansu Province, Lanzhou Veterinary Research Institute, Chinese Academy of Agricultural Sciences, Lanzhou, Gansu Province 730046, People's Republic of China

${ }^{3}$ Jiangsu Co-innovation Center for the Prevention and Control of Important Animal Infectious Diseases and Zoonoses, Yangzhou University College of Veterinary Medicine, Yangzhou, Jiangsu Province 225009, People's Republic of China

Full list of author information is available at the end of the article
}

Reactivation of a latent infection in immunocompromised individuals can cause fatal toxoplasmatic encephalitis, myocarditis and pneumonitis [11, 12]. The immunocompromised patients are also at risk of severe disease following primary infection or reactivation of chronic infection $[13,14]$. Infection acquired during pregnancy can cause severe damage to the fetus, such as long-term disabling sequelae, stillbirths or fetal death [15].

Toxoplasma gondii has been considered a single species in the genus Toxoplasma. Early studies on the parasite strains from North America and Europe identified limited genetic diversity, which were classified into genetic types I, II, and III [16]. Recent multilocus polymerase chain reaction-restriction fragment length polymorphism (PCR-RFLP) genotyping of approximately 1500 samples worldwide has revealed 189 different genotypes, with the Toxoplasma genome database (ToxoDB) PCR-RFLP (http://www.toxodb.org/toxo/) genotypes \#1 (type II), \#2 (type III) and \#3 (type II variant) found worldwide, and highly prevalent in Europe, genotypes \#1, \#2, \#3, \#4 and \#5 prevalent in North America, genotypes \#2 and \#3 (type III and type II variant) 
prevalent in Africa, and genotypes \#9 (Chinese 1) and \#10 (type I) prevalent in East Asia [17]. The consequences of infection with $T$. gondii may depend on parasite genotypes and host species [18]. In humans, disease manifestations range from asymptomatic to severe acute toxoplasmosis $[4,19]$. Type I or type I variants are more likely to be associated with severe toxoplasmic retinochoroiditis [20], and the atypical isolates often cause severe acute or disseminated toxoplasmosis in immunocompetent individuals [19]. Type I isolates are uniformly lethal to out-bred mice, while type II and III isolates are significantly less virulent [21].

Clinical symptoms of $T$. gondii infection are nonspecific and unreliable for diagnosis $[4,22]$. The traditional diagnosis of $T$. gondii infection usually depends on bioassays and serological tests, with the limitations in detection or differentiating parasite strains [23, 24]. The detection of $T$. gondii infection by molecular methods is appealing, due to their high sensitivity and specificity [25]. Moreover, abundant T. gondii genotypes have been identified from various mammals and birds using PCRbased molecular methods $[17,18]$. In this review, we conducted English literature searches in PubMed from 1948 to 2014 using the key words Toxoplasma gondii, toxoplasmosis, diagnosis, genetic characterization, genotyping and serotyping, and summarize the biotechnological advances in diagnosis of toxoplasmosis and typing of T. gondii.

\section{Traditional, non-DNA-based diagnostic methods Microscopic diagnosis}

The detection of $T$. gondii in fecal, water, environmental and tissue samples has traditionally relied on microscope examination. However, identification based on light microscopy alone is less sensitive and unreliable. The oocysts in fecal, water and environment can be enriched from large volumes of samples by filtration or centrifugation for examination, and the tissue cysts can be stained, which helps to distinguish the parasites from host cells. Giemsa and Haematoxylin and Eosin (HE) staining is simple and cost-effective, and commonly used for this purpose [26-28]. Periodic acid schiff (PAS) can stain amylopection granules in bradyzoites [26]. These methods are relatively time consuming and require considerable skill to obtain reliable detection results. Electron microscope is also employed to detect tissue cysts in mouse brain and oocysts in the small intestine of infected cats, but it is difficult to be applicable for routine use $[29,30]$.

\section{Bioassay}

The isolation of $T$. gondii by bioassay using laboratory animals is generally considered as the gold standard for detection of T. gondii infection. Secretions, excretions, body fluids, lymph nodes, muscle and brain tissues are possible specimens used for the isolation [31, 32]. Mice and cats are commonly used for bioassay of $T$. gondii. To achieve higher success rate in $T$. gondii isolation, INF-gamma knockout mice are preferred, due to high sensitivity of these mice to T. gondii infection. Alternatively, normal mice may be immune suppressed by administrating dexamethason $(10-15 \mu \mathrm{g} / \mathrm{ml})$ in drinking water during the course of bioassay to increase success rate. Cats can be used to detect small number of viable $T$. gondi in meat because larger volumes of tissues can be fed to cats, therefore increasing the sensitivity. Overall, the bioassay is expensive and time-consuming (usually requires 6 weeks). Thus, it cannot be used for large-scale screening.

\section{Serological assays}

T. gondii infection usually shows no or non-specific clinical symptoms in most individuals, whose diagnosis mainly relies on serological tests. A variety of serological tests, such as dye test (DT), modified agglutination test (MAT), enzyme-linked immunosorbent assays (ELISA), immunosorbent agglutination assay (ISAGA), indirect fluorescent antibody test (IFAT) and indirect haemagglutination assays (IHA), have been developed to detect different antibody classes or antigens (Table 1). IgM antibodies are detectable about 1 week after the infection and remain for several months or years. So the detection of IgM antibodies alone is insufficient for the establishment of acute infection. IgA antibodies are considered to be a marker of acute infection, which are produced earlier than IgM, and may persist for several months. The shorter period of IgE may give a greater indication of current infection. The presence of IgG antibodies suggestions the occurrence of infection, but does not provide any information about the timing of infection.

\section{Dye test (DT)}

DT, first developed by Sabin and Feldman in 1948, has been considered as gold standard for the detection of anti-T. gondii antibodies in humans [33, 34]. DT is both specific and sensitive in humans, but may be unreliable in cattle and avian species $[35,36]$. The major disadvantage of DT requires live parasites and healthy human serum as an accessory factor, severely limiting the availability of the DT [37]. The test is potentially hazardous, and requires a high degree of technical expertise, thus only performed in reference laboratories. Though tachyzoites prepared from cell culture can be routinely used in DT, the false negative results may occur in some cases. Therefore, tachyzoites prepared from mice are preferred for DT [38]. 
Table 1 Summary of serological methods for detection of T. gondii infection

\begin{tabular}{|c|c|c|c|}
\hline Serological methods & Antigens or antibodies used & Antibody/antigen type tested & References \\
\hline DT & Live tachyzoite & $\lg G, \lg M, \lg A$ & [33] \\
\hline MAT & Formalin-fixed tachyzoite & $\lg G$ & [39] \\
\hline IFAT & Killed whole tachyzoite & $\lg G, \lg M$ & {$[55,76]$} \\
\hline IHA & Tanned red blood cells sensitized with soluble antigens & $\lg G$ & [50] \\
\hline ELISA & Tachyzoite lysate antigen, recombinant antigens, specific antibodies & $\lg G, \lg M, \lg A$, antigens & {$[192,193]$} \\
\hline ISAGA & anti-human IgM antibodies & $\lg M$ & [79] \\
\hline LAT & Soluble antigen coated latex particles & $\lg G, \lg M$ & {$[194,195]$} \\
\hline PIA & Antigen coated gold nanoparticles & $\lg G$ & [90] \\
\hline WB & Tachyzoite lysate antigen, recombinant antigens & $\lg G, \lg M$ & [196] \\
\hline $\mathrm{ICT}$ & Antigens or antibodies labeled with colloidal gold & $\lg G, E S A$ & {$[83,84]$} \\
\hline Avidity test & tachyzoite lysate antigen, recombinant antigens & $\lg G, \lg A, \lg E$ & {$[100]$} \\
\hline
\end{tabular}

\section{Modified agglutination test (MAT)}

For MAT test, formalin-fixed T. gondii tachyzoites are added to U-shaped microtiter plates and diluted test sera are then added. Positive serum samples will produce a thin mat of agglutination, while negative samples will produce a compact pellet of precipitated tachyzoites at the bottom of the well [39]. This test was first described by Fulton and Turk [40] with low specificity and sensitivity, due to the binding of normal IgM to the surface of the parasite, and improved by preparing the antigen using a buffer containing 2-mercaptoethanol to remove non-specific IgM. This test detects IgG antibodies, without limitation of host species, but the false negative results may occur during early stages of acute infection. The specificity and sensitivity of MAT are comparable to the DT in most species, but it can produce high false negative results in dogs $[41,42]$.

The results of MAT differ, depending on the preservative used to prepare the antigen. MAT using acetone in place of formalin can detect IgG antibodies in acute infection, which is very useful in diagnosis of toxoplasmosis in AIDS patients, and acute glandular toxoplasmosis [43]. In addition, MAT can also be used to detect cardiac fluids for the survey of $T$. gondii infection in slaughtered sheep for human consumption, with higher sensitivity than other serological tests [44]. MAT is so simple and accurate that, it is convenient both for laboratory diagnosis and for epidemiological survey.

\section{Latex agglutination test (LAT)}

In this test, soluble antigen is coated on latex particles, and agglutination is observed when the positive serum is added. LAT is rapid and easy to perform to detect anti-T. gondii IgG antibodies. LAT has a sensitivity of 86-94\% and specificity of $100 \%$ in humans, a low sensitivity of $78.6 \%$ and specificity of $61.9 \%$ in sheep $[45,46]$. Thus, LAT is often used as a screening tool in epidemiologic survey due to the simplicity of performance, but the positive result requires further examination using other serological tests [47].

LAT has also been modified to detect anti- $T$. gondii IgM antibodies in humans for diagnosis of recent infection. Sato et al. [48] isolated microsomal antigen Sp-2 reactive with anti- $T$. gondii antibodes, whose reactivity with IgM and IgG antibodies varies with the concentration. Sp-2 antigen only reacts with IgM when latex particles are sensitized with less than or equal to $100 \mathrm{mg}$ of this antigen/mg of particles. Based on this unique reaction of the antigen, a passive latex agglutination reaction to detect IgM antibodies has developed. Cambiaso et al. [49] utilized proteinase K-treated antigen-coated particles to establish LAT for the detection of IgM antibodies in humans, with an advantage of no significant interferences by IgG antibodies, or by rheumatoid factor or antinuclear antibodies.

\section{Indirect hemagglutination test (IHA)}

The principle of IHA is that the tanned red blood cells sensitized with $T$. gondii soluble antigen can be agglutinated by the positive serum [50]. However, detectable IHA IgG antibodies are later than DT, so acute and congenital infections are likely to be missed by this test [51, 52]. In animals, the detected antibodies with lower titers may be non-specific [50]. The IgG-IHA test is simple and rapid, thus recommended for mass screening in epidemiologic surveys [53]. Yamamoto et al. [54] described a modified IgM-IHA test by stabilized human red cells coated with a $T$. gondii heat-stable alkaline-solubilized extract, which can be used for the serodiagnosis of acute toxoplasmosis in humans, with a sensitivity of $100 \%$ and specificity of $98.5 \%$.

\section{Indirect fluorescent antibody test (IFAT)}

IFAT is a simple test detecting both IgG and IgM antibodies, and has been widely used in detection of $T$. gondii antibodies in humans and animals [55-58]. Killed 
T. gondii tachyzoites are incubated with test serum, the fluorescent anti-species antibodies are added, and the result is read under a fluorescence microscope. The test shows sensitivities of $80.4-100 \%$ and specificities of 91.4-95.8\% [59, 60]. Fluorescent-labeled antibodies for a variety of species are commercially available, and the method is relatively inexpensive. However, a fluorescence microscope is necessary for the test, and the results are read by eye, so individual variation may occur. It may be difficult to find some species-specific conjugates, and there is a risk of possible cross-reactivity with rheumatoid factor and anti-nuclear antibodies [61].

\section{Enzyme-linked immunosbsorbent assay (ELISA)}

The ELISA system usually includes the solid phase antigen or antibody, enzyme labeled antigen or antibody, and the substrate of the enzyme reaction, which can be modified to test both antibodies and antigens (Fig. 1). ELISA can be automated so that a large number of samples can be simultaneously tested. There have been different types of ELISA developed to detect $T$. gondii antibodies or antigens, such as indirect ELISA, and sandwich ELISA.

In the indirect ELISA, the antigen is coated onto the solid phase and the sample containing antibodies are added, the antigen-antibody reaction is enhanced by the addition of a secondary enzyme-linked antibody, and the reaction can be evaluated by quantification of the color that develops (Fig. 1a). The tests are almost all used to detect anti-T. gondii IgG, IgM, and IgA antibodies rather than antigens, depending on the enzyme-linked antibody type [62]. The conventional indirect ELISAs using tachyzoite lysate antigen (TLA) as coating antigen show a high degree of agreement with DT, MAT or IFAT detecting IgG or IgM antibodies in humans and animals [61-63]. Despite the satisfactory results, TLA-based ELISA may vary significantly between laboratories, or between batches, thus difficult to standardize, and the test results are difficult to evaluate. An alternative approach is to use recombinant proteins, with an advantage of the precise antigen and easy standardization. In the past 20 years, numerous recombinant antigens, including granule antigens GRA1, GRA2, GRA4, GRA6, GRA7, and GRA8, rhoptry proteins ROP1 and ROP2, matrix protein MAG1, microneme proteins MIC2, MIC3, MIC4, and MIC5, and surface antigens SAG1 and SAG2, have been expressed in Escherichia coli or yeast, and their potential diagnostic value was evaluated in humans or animals by ELISA to detect specific IgG and IgM antibodies [23, 64-68]. Combinations of recombinant antigens have been shown more sensitive and specific than using single antigen. For example, combinations of SAG2A, GRA2, GRA4, ROP2, GRA8 and GRA7 are potentially useful to detect IgG antibodies in humans with recently acquired infection [69], ROP1, SAG1, GRA7, GRA8, and GRA6 are promising to detect specific IgM antibodies [70], while GRA7 and GRA8 are used to detect specific IgA antibodies [23, 71]. Hill et al. [72] identified a sporozoite-specific embryogenesis-related protein (ERP), which can react with oocyst-specific antibodies, and be used to differentiate oocyst-induced infection from tissue cyst-induced infection.

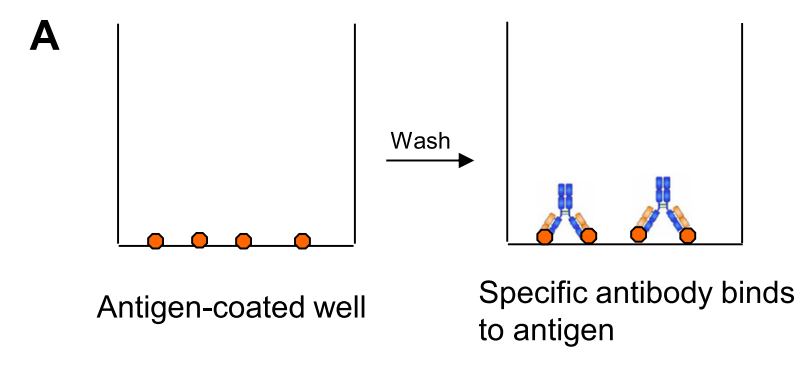

B

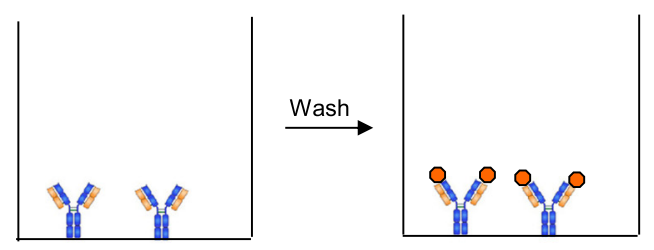

Specific antibody-coated well
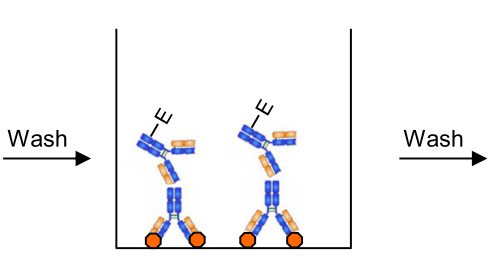

Enzyme-conjugated secondary antibody binds to specific antibody

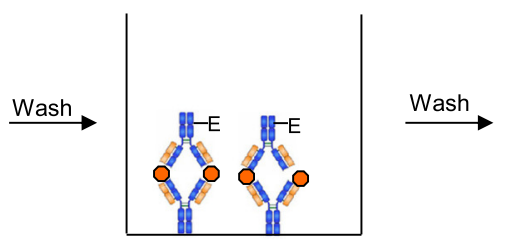
Enzyme-conjugated antibody
binds to specific antigen

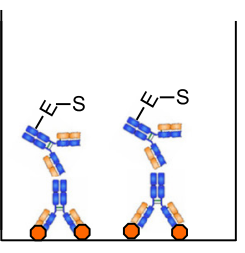

Substrate is added and color is developed

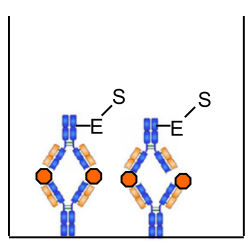

Substrate is added and color is developed

Fig. 1 Schematic diagram of ELISA. a Indirect ELISA system almost all used for detection of T. gondii antibodies rather than antigens involves the specific antigen coated onto the solid phase, enzyme-conjugated secondary antibody and substrate. b Sandwich ELISA system detecting T. gondii antigens involves the specific antibody coated onto the solid phase, enzyme-conjugated antibody and substrate 
In the sandwich ELISA, the antigens or antibodies are coated onto the solid phase, and the sample containing antibodies or antigens are added. After incubation and washing, the antibody-antigen complex is attached to the solid phase. The captured antibodies or antigens are detected by the addition of enzyme-labeled specific antigens or antibodies (Fig. 1b). The sandwich ELISA has been developed to detect $T$. gondii antibodies and antigens. The sandwich ELISA with TLA is more sensitive and more specific to detect human IgM antibodies than IFAT [62], and the sandwich ELISA with recombinant P35 is more specific for the acute infection than IgMELISA using TLA [73, 74]. Another sandwich ELISA with anti-MIC10 antibody prepared from two different species can be used to detect circulating antigen MIC10 for early diagnosis of toxoplasmosis [75]. ELISA is simple, economical and easily adoptable for field use. Using an improved ELISA format, it is possible to detect $T$. gondii specific IgM, IgG and IgA antibodies, and circulating antigens. However, development of an ELISA test is labor-intensive and time-consuming, especially when evaluating its sensitivity and specificity.

A modified ELISA technique, dot-ELISA, in which the antigen-antibody reaction is performed on nitrocellulose in place of the polystyrene plate, has been established to detect $T$. gondii antigens and antibodies $[76,77]$. This test is sensitive, and easy to perform in comparison with standard ELISA and no special equipment is required $[76,78]$.

\section{Immunosorbent agglutination assay (ISAGA)}

In this test, microtiter plates are coated with anti-human IgM antibodies, and the serum sample is added to the wells for $2 \mathrm{~h}$ at $37^{\circ} \mathrm{C}$ to allow the binding of IgM. The plates are washed and the suspension of fixed tachyzoites is added to the wells, which are incubated in moist chamber overnight at $37{ }^{\circ} \mathrm{C}$. The specific IgM in serum sample will bind to the anti-species IgM and agglutinate fixed parasite antigens, which is observed as that of MAT [79]. This test is simpler and easier to perform than the IgM-ELISA, but it requires large numbers of $T$. gondii tachyzoites. Thereafter, the IgM-ISAGA is modified by replacing $T$. gondii tacyzoites with latex beads coated with soluble antigens [80]. IgM-ISAGA can be used for the diagnosis of acute acquired and congenital T. gondii infection.

\section{Immunochromatographic test (ICT)}

The immunochromatographic test is a rapid detection technique in which the colloidal gold-labeled antigen or antibody is used as the tracer, and the cellulose membrane is used as the solid support (Fig. 2) [81, 82], and the detection antibodies or antigens are dropped at the sample pad on the nitrocellulose membrane, which will slowly infiltrate the conjugated pad through capillary action, and antibody-antigen complexes show colloidal gold color reaction [83]. A rapid immunochromatographic strip using colloid gold conjugated antiexcretory/secretory antigens (ESA) IgG antibodies was developed to detect ESA in acute infection of $T$. gondii as early as 2-4 days post-infection, showing high agreement with ELISA in sensitivity and specificity [83]. The antibody detection results of GRA7-, SAG2based ICT are consistent with those of LAT and ELISA $[84,85]$. As ICT is easy, rapid, and convenient to perform, and no special equipment is required, it is suitable for field application.

\section{Piezoelectric immunoagglutination assay (PIA)}

The agglutination of antigen-coated gold nanoparticles in the presence of the specific antibodies can be detected by a piezoelectric device, which has been used for the detection of parasite infection [86-89]. Wang et al. [90] developed a piezoelectric immunoagglutination assay for $T$. gondii antibodies, whose detection results were in satisfactory agreement with those of ELISA. In contrast to the conventional piezoelectric assays, the immobilization of antibody or antigen on a piezoelectric crystal is not necessary.

\section{Western blotting (WB)}

WB can be uses as an aid to conventional serological test described previously. In this test, sera are reacted with $T$. gondii antigen on a membrane transferred from a polyacrylamide gel, and the resulting banding patterns are matched with known molecular weight.

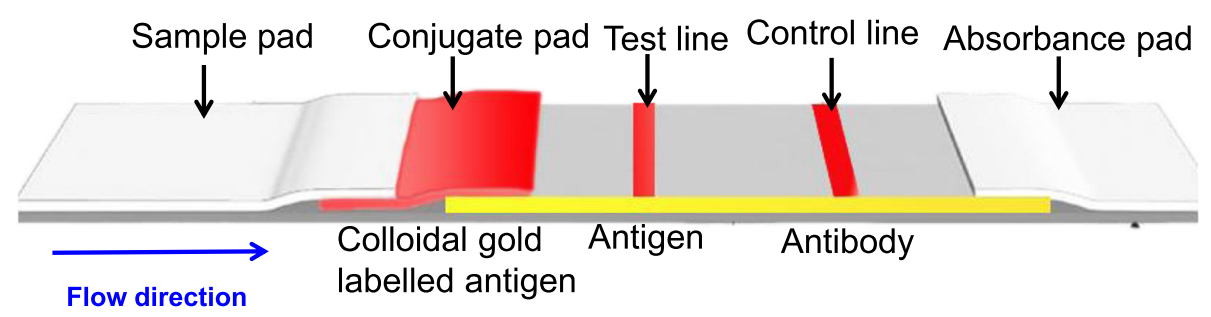

Fig. 2 Schematic diagram of the immunochromatographic test for detection of T. gondii-specific antibody. The colloidal gold-labeled antigen or antibody is used as the tracer and the cellulose membrane is used as the solid support 
An immunoblot test exhibited a specificity of $100 \%$ and a sensitivity of $98.5 \%$ to detect specific anti-T. gondii IgG antibodies in human saliva [91], but showed a lower specificity of $83 \%$ for toxoplasmic chorioretinitis [92]. WB is a useful complementary tool for the early postnatal diagnosis of congenital toxoplasmosis, as the combination of IgA- and IgM-ELISAs, IgG and IgM WB, and the combination of both techniques shows a sensitivity of $94 \%, 94 \%$, and $100 \%$ during the first 3 months of life, respectively [93].

\section{Avidity test}

The presence of anti- $T$. gondii IgG antibodies implies the parasite infection, but gives no information on infection time; anti- $T$. gondii IgM is not an accurate marker of acute infection [94-96], nor is IgA a specific marker of the acute phase [97]. The IgG avidity test, first described by Hedman et al. [98], is now widely used to differentiate between acute and chronic $T$. gondii infections [99].

The avidity of $T$. gondii antigen to specific antibodies can vary during the course of infection. During the early stage of infection, avidity values are low, and increase with duration of infection [97, 98]. Thus, the avidity test can distinguish acute and chronic infection of T. gondii. In the test, sera are run with or without treatment with urea, or other protein denaturing agents, and the difference in titers can be used to determine recent infection. The test is applicable in IgG, IgA, and IgE by different serological procedures, such as ELISA and WB [100-103]. However, there are limitations to the test. T. gondii-specific low-avidity IgG antibodies in pregnant women may persist for months $[104,105]$, and treatment of $T$. gondii may delay the avidity maturation during pregnancy [106-108]. High concentration of antibodies in serum sample may affect the results of avidity test, making it necessary to improve detection methods of antibody avidity [109].

\section{Imaging techniques}

Imaging techniques, such as computed tomography (CT), magnetic resonance imaging (MRI), and ultrasonography (US), are not specific, but can facilitate the diagnosis of toxoplasmosis and monitor the therapeutic effect [110-115]. As immuno-deficient patients often develop encephalitis and brain abscesses when infected with T. gondii, CT and MRI can be used to locate the lesions. CT is often used as an initial screening test, and MRI is more suitable for the determination of the damage extent [113]. For congenital toxoplasmosis, US is recommended for prenatal diagnosis [116, 117], and CT can detect diffuse hydrocephalus and brain calcifications of toxoplasmosis in infants [115].

\section{Molecular methods based on detection of parasite nucleic acids}

Molecular methods are used in addition to conventional serological methods for the diagnosis of toxoplasmosis. Conventional methods are usually not misleading, but are limited in prenatal cases or in immunocompromised patients. For example, a mother may be diagnosed accurately by serology that she has had a current infection during pregnancy and so her baby is potentially at risk of congenital infection but the serology results cannot confirm whether the parasite has been transferred to the baby. However, the molecular diagnostic techniques may do so.

\section{Conventional PCR}

Due to inherent limitations of traditional diagnostic methods, PCR can be used in addition to serology to diagnose T. gondii infection. PCR is an efficient in vitro enzymatic amplification method that allows specific amplification of DNA from minute amounts of starting material in a short time [118]. To achieve high sensitivity, several multicopy targeting genes are usually used for the detection of $T$. gondii in biological samples, including the B1 gene, the 529 bp repeat element and the internal transcribed spacer (ITS-1) or 18S rDNA sequences (Table 2). The presence of a parasitaemia is seldom detected therefore PCR of blood has a low negative predictive value. Several other single-copy genes, such as SAG1, SAG2, and GRA1, have also been used as PCR targets in some laboratories.

The first PCR method for T. gondii detection, targeting the B1 gene, was established in 1989 [119]. This method has widely been used in prenatal diagnosis of congenital toxoplasmosis and T. gondii infection in immunocompromised patients [120-124]. PCR with the 529 bp repeat element was reported to be 10 - to 100-times more sensitive than the B1 gene $[125,126]$. The multicopy ITS-1 and 18S rDNA have also been used as the targets in a few studies, showing a similar sensitivity of the $\mathrm{B} 1$ gene [127-129].

To further improve the sensitivity and specificity, nested PCRs based on the B1 gene, the 529 bp repeat element, and ITS-1 sequences have been developed $[130,131]$. In the nested PCR, two sets of primers are used in two successive PCRs. The products of the first reaction are used as templates for the second PCR. For a given targeting gene, nested PCR is more sensitive than the conventional PCR. The detection limit of the $529 \mathrm{bp}$ repeat element-nested PCR is $640 \mathrm{fg}$ of parasite DNA, while the rate for B1-nested PCR is 5.12 pg [130], and the nested PCR targeting the B1 gene is more sensitive than targeting ITS-1 sequence [131].

The sequence of the PCR product must be verified to provide adequate diagnostic specificity. The conventional 
Table 2 Summary of the molecular approaches used for detection and genetic characterization of T. gondii

\begin{tabular}{|c|c|c|c|}
\hline Molecular methods & Main purposes & DNA target regions & References \\
\hline Conventional PCR & Species detection & B1 gene, 529 bp repeat element, $18 \mathrm{~S}$ rDNA gene, SAG1, SAG2, and GRA1 & {$[18,147,148,197]$} \\
\hline Real-time PCR & Species detection & B1 gene, 529 bp repeat element, $18 \mathrm{~S}$ rDNA gene, SAG1 & {$[198,199]$} \\
\hline LAMP & Species detection & $\begin{array}{l}\text { 529-bp repetitive element, B1, SAG1, SAG2, GRA1, oocyst wall protein } \\
\text { genes }\end{array}$ & {$[145,200]$} \\
\hline Microsatellite analysis & Genotyping & $\begin{array}{l}\text { TUB2, W35, TgM-A, B18, B17; M33, IV.1, XI.1, M48, M102, N60, N82, AA, N61, } \\
\text { and N83 }\end{array}$ & [156] \\
\hline Multilocus sequence typing & Genotyping & BTUB, SAG2, GRA6, and SAG3 & {$[162,163]$} \\
\hline PCR-RFLP & Genotyping & SAG1, SAG2, SAG3, BTUB, GRA6, c22-8, c29-2, L358, PK1 and Apico & [18] \\
\hline RAPD-PCR & Genotyping & Genomic DNA & [177] \\
\hline $\begin{array}{l}\text { High-resolution melting (HRM) } \\
\text { analysis }\end{array}$ & Genotyping & B1 gene & [182] \\
\hline
\end{tabular}

technique is hybridization with a specific probe by Southern blotting, which requires an additional 12$24 \mathrm{~h}$ to complete. The PCR-ELISA is an alternative technique, in which PCR products hybridize to an immobilized capture probe. The assay thus measures sequences internal to the PCR product [132]. Martinez et al. [133] developed a rapid PCR-ELISA assay using polystyrene beads for the detection of $T$. gondii DNA, whose detection threshold is equivalent to Southern blotting.

\section{Real-time PCR}

Real-time PCR can detect low concentrations of target DNA and quantify starting copies of specific template DNA. The amplification product is measured during each cycle using probes or intercalating dyes, and can be quantified by a standard of known concentration. Realtime PCR has been successfully used to detect $T$. gondii DNA in human blood, cerebrospinal fluid, aqueous humor, amniotic fluid, and other samples [134-137]. The real-time PCR is also used to evaluate toxoplasmosis progression and treatment efficacy, since it can estimate the intensity of $T$. gondii infection [138]. The real-time PCR assay with the B1 gene is considered as the best-performing technique for diagnosis of congenital toxoplasmosis, compared with conventional PCR and nested-PCR [139]. As a rapid closed-tube system, realtime PCR eliminates the possible risk of contamination and produces reproducible quantitative results. Thus it is suitable for standardization [140].

Opsteegh et al. [141] described a sequence-specific magnetic capture method for the isolation of $T$. gondii DNA from large samples of tissue, which can overcome the heterogenous distribution of $T$. gondii tissue cysts, and the small size of the sample. This technique combined with real time PCR can be used in meat samples, and provide an alternative for bioassays to evaluate the burden of $T$. gondii in various tissues of food-borne animals [142, 143].

\section{Loop-mediated isothermal amplification (LAMP)}

LAMP is a unique DNA amplification technique under isothermal conditions using four primers that recognize six regions on the target DNA [144]. This method is slightly more sensitive than conventional PCR, but slightly lower than real time PCR $[145,146]$. LAMP assays targeting the $T$. gondii SAG1, 529-bp repetitive element, B1, SAG2, GRA1, oocyst wall protein (OWP) genes, and 18S rRNA were developed for the veterinary and medical samples, and water samples [145, 147-152]. The LAMP based on SAG1 can detect T. gondii in the blood of experimentally infected pigs as early as 2 days post-infection, suggesting that this approach can be used for early diagnosis of toxoplasmosis [145]. The detection limit of both the B1- and OWP-LAMP assays is 0.1 tachyzoites DNA [151]. LAMP assays targeting SAG1, SAG2, and B1 are useful to detect $T$. gondii in blood samples of humans [147, 150,153, 154], as well as in water resources [155]. As LAMP requires only a water bath or heat block, and allows visual detection of amplification products, it may be an alternative diagnostic method in the field, where sophisticated and expensive equipment may not be available [144]. However, in our hands, the LAMP seems extremely sensitive to contamination; therefore a rigorous quality control is essential to rule out false positives.

\section{Genotyping methods based on molecular technologies}

For epidemiological studies, it is important to identify genotypes of $T$. gondii infection, and some molecular technologies, including microsatellite analysis, multilocus sequence typing, PCR-RFLP, RAPD-PCR, and highresolution melting (HRM) analysis, have been developed. 


\section{Microsatellite analysis}

Microsatellite (MS) sequences are tandem short DNA motif repeats that are widespread in eukaryotic genomes and the sequences usually change due to insertion or deletion of repeat units. The numbers of repeat units differ in a population, thus producing multiple alleles at an MS locus. The tandem repeats in T. gondii are often simple, and composed with as few as 2 nucleotides, and occur 2-20 times [156-159]. A total of 15 MS markers, including TUB2, W35, TgM-A, B18, B17; M33, IV.1, XI.1, M48, M102, N60, N82, AA, N61, and N83, have been used to genotype $T$. gondii in different laboratories [156, 157, 160, 161]. Ajzenberg et al. [156] developed an easy-to-use method for genotyping $T$. gondii in a single multiplex PCR assay using 15 microsatellite markers, in which the 8 MS markers (TUB2, W35, TgM-A, B18, B17, M33, IV.1, and XI.1) could differentiate types I, II, and III from all the atypical genotypes, and the other 7 markers (M48, M102, N60, N82, AA, N61, and N83) could enhance genetic resolution in differentiating closely related isolates within one haplogroup or clonal lineage [158]. The 15-MS multiplex assay is the best tool available to identify $T$. gondii isolates genetically different or identical, i.e., to identify the infection source in an outbreak, laboratory contamination and mixed infections [158]. The limitation of this assay is the requirement for an automated sequencer. In addition, small amount of DNA from biological samples could cause the absence of detectable peaks or peaks of low intensity, which is undistinghishable from nonspecific PCR products [156].

\section{Multilocus sequence typing (MLST)}

Multilocus sequence typing (MLST) is based on DNA sequence polymorphisms, including the single nucleotide polymorphisms (SNPs), and deletion and insertion of nucleotides, which has the highest resolution among all typing methods when enough genomic DNA is available [18]. Several studies have revealed some alleles unique to the Brazil isolates, including 5'-SAG2, 3'-SAG2, BTUB, GRA6, and SAG3 [162, 163]. However, this approach is not a good choice for clinical samples, as a large quantity of genomic DNA is required for this assay.

\section{PCR-RFLP}

The PCR-RFLP is based on the ability of restriction endonucleases to recognize SNPs, digest PCR products and subsequently display distinct DNA banding patterns on agarose gels electrophoresis [16]. How and Sibley [16] identified 3 predominant lineages (types I, II and III) from $106 T$. gondii isolates from humans and animals by PCR-RFLP using 6 markers. Since then, several different sets of multilocus PCR-RFLP markers have been employed to characterize individual $T$. gondii isolates in different laboratories [164-169]. The conventional multilocus PCR-RFLP relies on single-copy polymorphic DNA sequences, and usually requires a relatively large amount of parasite DNA. Thus, it is difficult to genotype T. gondii in biological samples, due to the limited parasite DNA available.

To alleviate this problem, a multiplex multilocus nested PCR-RFLP (Mn-PCR-RFLP) was developed, using 10 genetic markers, including SAG1, SAG2, SAG3, BTUB, GRA6, c22-8, c29-2, L358, PK1 and Apico [170]. The sensitivity of this method is increased by at least 10 times, comparing with conventional PCR-RFLP [18]. The advantage of this method is that only a limited amount of DNA sample is needed, and it is very useful when only small amounts of 'precious' samples are available. Mn-PCR-RFLP has widely been applied to the genetic typing of clinically positive samples, and a large amount of data regarding genetic diversity and population structure of the parasite were generated [171-176]. The major precaution for this assay is that, if the contamination occurs in the early cycles of PCR, erroneous results may be generated. To avoid error results of PCR amplification in Mn-PCR-RFLP, the negative control has to be included in each experiment. In addition, several reference $T$. gondii isolates should be included to monitor the efficiency of PCR amplification and restriction enzyme digestion [18].

\section{Random amplified polymorphic DNA-PCR (RAPD-PCR)}

RAPD-PCR is a PCR-based technique that can be used to identify DNA polymorphisms without predetermined genetic data. It is based on the amplification of genomic DNA using single short arbitrary primers under low stringency conditions. RAPD-PCR is good for detecting genetic differentiation of closely related organisms, and has been employed to identify the genotype of $T$. gondii strains [177-179]. T. gondii could be classified into virulent and avirulent strains based on the murine virulence by RAPD-PCR using arbitrary primers, and some primers are useful to identify the virulence markers [177]. This technique is quick, simple and efficient. However, RAPD band profiles may be difficult to reproduce between, even within laboratories, if personnel, equipment or conditions are changed. Only a small amount of DNA is required for this assay, but it must be highly pure [180]. Thus, RAPD-PCR cannot be directly used for the clinical samples.

\section{High-resolution melting (HRM)}

HRM is a homogeneous, close-tube and post-PCR method to analyze genetic variations, which can characterize polymorphisms based on their melting temperatures related to their sequences, lengths and GC contents [181]. Based on a single SNP of the multicopy B1 gene, HRM analysis can correctly classify $T$. 
gondii strains into three distinct types [182]. HRM is more informative than the microsatellite analysis, therefore, becoming a supplementary test for multilocus microsatellite analysis [182, 183]. This assay was developed to directly genotype $T$. gondii infection from biological samples, with a higher genotyping capacity using multi-copy gene than single-copy gene, thus avoiding cell culture or bioassay [183]. HRM is a potentially simple solution for genotyping, mutation scanning, and sequence matching.

\section{Serotyping methods based on polymorphic polypeptides}

$T$. gondii infection induces a strong and persistent humoral immune response in the hosts. Some T. gondii antigenic proteins present sequence polymorphisms in different clonal types. The polymorphic peptides from the T. gondii antigens SAG2A, GRA3, GRA6, and GRA7 can accurately recognize the type I, II, and III in mice, and peptides from GRA6 can distinguish type II from non-type II infection [184]. Xiao et al. [185] developed ELISAs based on polymorphic peptides derived from three dense granule antigens GRA5, GRA6 and GRA7, which can distinguish type III- from type I-infections in humans. Several trials have been made to type T. gondii infections using ELISA formats, in which synthetic peptides are coupled via keyhole limpet hemocyanin, or directly to the solid phase [185-188]. The recombinant antigens can also be used for serotyping [189]. The peptide-microarray tests for $T$. gondii serotyping in humans and cats have been established, which are more sensitive than peptide-ELISAs [190, 191]. As serotyping is fast, inexpensive, relatively noninvasive, and there is no need to isolate parasites, this technique has the potential to become the method of choice for typing $T$. gondii in humans and animals. However, there are some limitations to the serologic assay. The selected peptides may be low sensitive, or cross-reactive in detecting recombinant strains [186]. The immunosuppressed patients may not produce sufficient specific antibodies to reach the detection threshold (DT titer of 1:64). Importantly, infection with the rare genotypes may induce entirely different humoral responses that may not be detectable using polymorphic polypeptides [184].

\section{Conclusion}

This review has attempted to provide a survey of available and developing biotechnologies for the detection of T. gondii infection, the diagnosis of toxoplasmosis and typing of $T$. gondii isolates. A key to effective management of toxoplasmosis is prompt and accurate diagnosis of disease. Though diagnosis of toxoplasmosis by detection of the parasite using microscopy and bioassays is regarded as the gold standard, its clinical diagnosis is more likely made by serological methods, and various serological tests have been established for the detection of $T$. gondii-specific antibodies, or circulating antigens. The molecular technologies based on nucleic acid amplification can be used in addition to conventional serological methods for the diagnosis of toxoplasmosis, and have been the focus of continued development in recent years. The recent development of the Mn-PCR-RFLP method makes it possible to genetically characterize or classify T. gondii from biological samples with high resolution. Serotyping methods based on polymorphic polypeptides have the potential to become the choice for typing $T$. gondii in humans and animals. With the increased usage of genomic, transcriptomic, and proteomic technologies and development of multilocus genotyping methods, the integrated use of molecular and bioinformatic technologies will be crucial to investigate genetic characterization of $T$. gondii, and could provide prospects for the design of entirely new diagnostic methods for toxoplamosis.

\section{Competing interests}

The authors declare that they have no competing interests.

\section{Authors' contributions}

$\mathrm{QL}$ and XQZ conceived and designed the review, and critically revised the manuscript. QL drafted the manuscript. ZDW and SYH contributed to drafting the manuscript. All authors read and approved the final manuscript.

\section{Acknowledgments}

Research in the authors' laboratories is supported, in part, by the National Key Basic Research Program of China ("973" Program) (Grant Nos. 2012CB722501, 2015CB150300), the Special Fund for Agro-scientific Research in the Public Interest" (Grant No. 201303042), the National Natural Science Foundation of China (Grant Nos. 31372430, and 31172316), the Science Fund for Creative Research Groups of Gansu Province (Grant No. 1210RJIA006), and the Open Funds of State Key Laboratory of Veterinary Etiological Biology, Lanzhou Veterinary Research Institute, Chinese Academy of Agricultural Sciences (Grant No. SKLVEB2013KFKT006). Associate Professor Chunlei Su at Department of Microbiology, the University of Tennessee, Knoxville, USA is thanked for comments on the draft manuscript.

\section{Author details}

${ }^{1}$ State Key Laboratory of Veterinary Etiological Biology, Key Laboratory of Veterinary Parasitology of Gansu Province, Lanzhou Veterinary Research Institute, Chinese Academy of Agricultural Sciences, Lanzhou, Gansu Province 730046, People's Republic of China. ${ }^{2}$ Key Laboratory of Jilin Province for Zoonosis Prevention and Control, Military Veterinary Institute, Academy of Military Medical Sciences, Changchun, Jilin Province 130122, People's Republic of China. ${ }^{3}$ Jiangsu Co-innovation Center for the Prevention and Control of Important Animal Infectious Diseases and Zoonoses, Yangzhou University College of Veterinary Medicine, Yangzhou, Jiangsu Province 225009, People's Republic of China.

Received: 3 February 2015 Accepted: 18 May 2015

Published online: 28 May 2015

References

1. Liu Q, Singla LD, Zhou H. Vaccines against Toxoplasma gondii: status, challenges and future directions. Hum Vacc Immunother. 2012;8:1305-8.

2. Moncada PA, Montoya JG. Toxoplasmosis in the fetus and newborn: an update on prevalence, diagnosis and treatment. Expert Rev Anti Infect Ther. 2012;10:815-28

3. Dubey JP. The history of Toxoplasma gondii-the first 100 years. J Eukaryot Microbiol. 2008;55:467-75. 
4. Tenter AM, Heckeroth AR, Weiss LM. Toxoplasma gondii: from animals to humans. Int J Parasitol. 2000;30:1217-58.

5. Paul M. Immunoglobulin G avidity in diagnosis of toxoplasmic lymphadenopathy and ocular toxoplasmosis. Clin Diagn Lab Immun. 1999;6:514-18

6. Cuomo G, D'Abrosca V, Rizzo V, Nardiello S, La Montagna G, Gaeta GB, et al. Severe polymyositis due to Toxoplasma gondii in an adult immunocompetent patient: a case report and review of the literature. Infection. 2013;41:859-62.

7. Neves Ede S, Kropf A, Bueno WF, Bonna IC, Curi AL, Amendoeira MR, et al. Disseminated toxoplasmosis: an atypical presentation in an immunocompetent patient. Trop Doct. 2011;41:59-60.

8. Carme B, Bissuel F, Ajzenberg D, Bouyne R, Aznar C, Demar M, et al. Severe acquired toxoplasmosis in immunocompetent adult patients in French Guiana. J Clin Microbiol. 2002;40:4037-44.

9. Candolfi E, de Blay F, Rey D, Christmann D, Treisser A, Pauli G, et al. A parasitologically proven case of Toxoplasma pneumonia in an immunocompetent pregnant woman. J Infection. 1993;26:79-81.

10. Abhilash KP, Roshine MK, Vandana K, Varghese GM. A probable case of acquired toxoplasmosis presenting as pyrexia of unknown origin in an immunocompetent individual. Int J Infect Dis. 2013;17:e1067-8.

11. Eza DE, Lucas SB. Fulminant toxoplasmosis causing fatal pneumonitis and myocarditis. HIV Med. 2006;7:415-20.

12. Saadatnia G, Golkar M. A review on human toxoplasmosis. Scand J Infect Dis. 2012:44:805-14.

13. Hermanns B, Brunn A, Schwarz ER, Sachweh JS, Seipelt I, Schroder JM, et al. Fulminant toxoplasmosis in a heart transplant recipient. Pathol Res Pract. 2001;197:211-5

14. Georgiev VS. Management of toxoplasmosis. Drugs. 1994;48:179-88.

15. Montoya JG, Liesenfeld O. Toxoplasmosis. Lancet. 2004;363:1965-76.

16. Howe DK, Sibley LD. Toxoplasma gondii comprises three clonal lineages: correlation of parasite genotype with human disease. J Infect Dis. 1995;172:1561-6.

17. Shwab EK, Zhu XQ, Majumdar D, Pena HF, Gennari SM, Dubey JP, et al. Geographical patterns of Toxoplasma gondii genetic diversity revealed by multilocus PCR-RFLP genotyping. Parasitology. 2014;141:453-61.

18. Su C, Shwab EK, Zhou P, Zhu XQ, Dubey JP. Moving towards an integrated approach to molecular detection and identification of Toxoplasma gondii. Parasitology. 2010;137:1-11.

19. Bossi P, Bricaire F. Severe acute disseminated toxoplasmosis. Lancet. 2004;364:579.

20. Grigg ME, Ganatra J, Boothroyd JC, Margolis TP. Unusual abundance of atypical strains associated with human ocular toxoplasmosis. J Infect Dis. 2001;184:633-9.

21. Sibley LD, Boothroyd JC. Virulent strains of Toxoplasma gondii comprise a single clonal lineage. Nature. 1992;359:82-5.

22. Boothroyd JC, Grigg ME. Population biology of Toxoplasma gondii and its relevance to human infection: do different strains cause different disease? Curr Opin Microbiol. 2002;5:438-42.

23. Kotresha D, Noordin R. Recombinant proteins in the diagnosis of toxoplasmosis. APMIS. 2010;118:529-42.

24. Bastien P. Molecular diagnosis of toxoplasmosis. T Roy Soc Trop Med Hyg. 2002;96:S205-15.

25. Switaj K, Master A, Skrzypczak M, Zaborowski P. Recent trends in molecular diagnostics for Toxoplasma gondii infections. Clin Microbiol Infect. 2005;11:170-6

26. da Silva PC, Shiraishi CS, Silva AV, Goncalves GF, Sant'Ana Dde M, Araujo EJ. Toxoplasma gondii: a morphometric analysis of the wall and epithelial cells of pigs intestine. Exp Parasitol. 2010;125:380-3.

27. Gordon SM, Gal AA, Hertzler GL, Bryan JA, Perlino C, Kanter KR. Diagnosis of pulmonary toxoplasmosis by bronchoalveolar lavage in cardiac transplant recipients. Diagn Cytopathol. 1993;9:650-4.

28. Dubey JP, Carpenter JL. Histologically confirmed clinical toxoplasmosis in cats: 100 cases (1952-1990). J Am Vet Med Assoc. 1993;203:1556-66.

29. Hutchison WM, Pittilo RM, Ball SJ, Siim JC. Toxoplasma gondii: scanning electron microscope studies on the small intestine of infected and uninfected cats. Acta Pathol Microbiol Scand B. 1979;87:393-5.

30. Sims TA, Hay J, Talbot IC. An electron microscope and immunohistochemical study of the intracellular location of Toxoplasma tissue cysts within the brains of mice with congenital toxoplasmosis. British J Exp Pathol. 1989;70:317-25.
31. Dubey JP, Darrington C, Tiao N, Ferreira LR, Choudhary S, Molla B, et al. Isolation of viable Toxoplasma gondii from tissues and feces of cats from Addis Ababa, Ethiopia. J Parasitol. 2013;99:56-8.

32. Dubey JP, Graham DH, De Young RW, Dahl E, Eberhard ML, Nace EK, et al. Molecular and biologic characteristics of Toxoplasma gondii isolates from wildlife in the United States. J Parasitol. 2004;90:67-71.

33. Sabin $A B$, Feldman $H A$. Dyes as microchemical indicators of a new immunity phenomenon affecting a protozoon parasite (Toxoplasma). Science. 1948;108:660-3.

34. Reiter-Owona I, Petersen E, Joynson D, Aspock H, Darde ML, Disko R, et al. The past and present role of the Sabin-Feldman dye test in the serodiagnosis of toxoplasmosis. Bull World Health Organ. 1999;77:929-35.

35. Dubey JP, Desmonts G, McDonald C, Walls KW. Serologic evaluation of cattle inoculated with Toxoplasma gondii: comparison of Sabin-Feldman dye test and other agglutination tests. Am J Vet Res. 1985;46:1085-8.

36. Dubey JP, Ruff MD, Camargo ME, Shen SK, Wilkins GL, Kwok OC, et al. Serologic and parasitologic responses of domestic chickens after oral inoculation with Toxoplasma gondii oocysts. Am J Vet Res. 1993;54:1668-72.

37. Ashburn D, Chatterton JM, Evans R, Joss AW, Ho-Yen DO. Success in the toxoplasma dye test. J Infection. 2001;42:16-9.

38. Udonsom R, Buddhirongawatr R, Sukthana Y. Is Sabin-Feldman dye test using T. gondii tachyzoites from animal inoculation still the best method for detecting Toxoplasma gondii antibodies. Southeast Asian J Trop Med Public Health. 2010;41:1059-64.

39. Desmonts $\mathrm{G}$, Remington JS. Direct agglutination test for diagnosis of Toxoplasma infection: method for increasing sensitivity and specificity. J Clin Microbiol. 1980;11:562-8.

40. Fulton JD, Turk JL. Direct agglutination test for Toxoplasma gondii. Lancet. 1959:2:1068-9.

41. Macri G, Sala M, Linder AM, Pettirossi N, Scarpulla M. Comparison of indirect fluorescent antibody test and modified agglutination test for detecting Toxoplasma gondii immunoglobulin $\mathrm{G}$ antibodies in dog and cat. Parasitol Res. 2009;105:35-40.

42. Zhu C, Cui L, Zhang L. Comparison of a commercial ELISA with the modified agglutination test for detection of Toxoplasma gondii antibodies in sera of naturally infected dogs and cats. Iran J Parasitol. 2012;7:89-95.

43. Montoya JG, Berry A, Rosso F, Remington JS. The differential agglutination test as a diagnostic aid in cases of toxoplasmic lymphadenitis. J Clin Microbiol. 2007:45(5):1463-8.

44. Villena I, Durand B, Aubert D, Blaga R, Geers R, Thomas M, et al. New strategy for the survey of Toxoplasma gondii in meat for human consumption. Vet Parasitol. 2012:183:203-8.

45. Mazumder P, Chuang HY, Wentz MW, Wiedbrauk DL. Latex agglutination test for detection of antibodies to Toxoplasma gondii. J Clin Microbiol. 1988;26:2444-6.

46. Oncel T, Vural G, Babur C, Kilic S. Detection of toxoplasmosis gondii seropositivity in sheep in Yalova by Sabin Feldman dye test and latex agglutination test. Turkiye Parazitol Derg. 2005;29:10-2.

47. Holliman RE, Barker KF, Johnson JD. Selective antenatal screening for toxoplasmosis and the latex agglutination test. Epidemiol Infect. 1990;105:409-14

48. Sato K, Ise Y, lida T, Suzuki T, Shimada K, Nishioka K. Detection of toxoplasma IgM antibody by passive latex agglutination reaction. J Immunol Methods. 1987;101:183-91.

49. Cambiaso CL, Galanti LM, Leautaud P, Masson PL. Latex agglutination assay of human immunoglobulin $\mathrm{M}$ antitoxoplasma antibodies which uses enzymatically treated antigen-coated particles. J Clin Microbiol. 1992;30:882-8

50. Dubey JP. Toxoplasmosis of Animals and Humans, vol. 313. Boca Raton: CRC Press; 2010.

51. Eissa MH, Abdel Salam AM, Antonious SN, Abdel Gafar AR, Morsy TA. Comparative study of the Sabin-Feldman dye test and the indirect haemagglutination test in serodiagnosis of toxoplasmosis. J Egypt Soc Parasitol. 1990;20:729-35.

52. Balfour AH, Bridges JB, Harford JP. An evaluation of the ToxHA test for the detection of antibodies to Toxoplasma gondii in human serum. J Clin Pathol. 1980;33:644-7.

53. Caruana LB. A study of variation in the indirect hemagglutination antibody test for toxoplasmosis. Am J Med Technol. 1980;46:386-91. 
54. Yamamoto Yl, Hoshino-Shimizu S, Camargo ME. A novel IgM-indirect hemagglutination test for the serodiagnosis of acute toxoplasmosis. J Clin Lab Anal. 1991;5:127-32.

55. Arthur MJ, Blewett DA. IFAT detection of IgG specific to toxoplasma in thoracic fluids from aborted lambs: evaluation on routine diagnostic submissions. Vet Rec. 1988;122:29-31.

56. Sucilathangam G, Palaniappan N, Sreekumar C, Anna T. IgG-indirect fluorescent antibody technique to detect seroprevalence of Toxoplasma gondii in immunocompetent and immunodeficient patients in southern districts of Tamil Nadu. Indian J Med Microbiol. 2010;28:354-7.

57. Rodrigues IM, Castro AM, Gomes MB, Amaral WN, Avelino MM. Congenital toxoplasmosis: evaluation of serological methods for the detection of antiToxoplasma gondii IgM and IgA antibodies. Mem Inst Oswaldo Cruz. 2009;104:434-40

58. Miller MA, Gardner IA, Packham A, Mazet JK, Hanni KD, Jessup D, et al. Evaluation of an indirect fluorescent antibody test (IFAT) for demonstration of antibodies to Toxoplasma gondii in the sea otter (Enhydra lutris). J Parasitol. 2002;88:594-9.

59. dos Santos TR, Nunes CM, Luvizotto MC, de Moura AB, Lopes WD, da Costa AJ, et al. Detection of Toxoplasma gondii oocysts in environmental samples from public schools. Vet Parasitol. 2010;171:53-7.

60. Shaapan RM, El-Nawawi FA, Tawfik MA. Sensitivity and specificity of various serological tests for the detection of Toxoplasma gondii infection in naturally infected sheep. Vet Parasitol. 2008;153:359-62.

61. Filice G, Meroni V, Carnevale G, Olliaro P, Carosi G. Comparison of ELISA and indirect immunofluorescence in the detection of $\lg G$ and $\operatorname{lgM}$ antitoxoplasma antibodies. Boll Ist Sieroter Milan. 1983;62:445-50.

62. Tomasi JP, Schlit AF, Stadtsbaeder S. Rapid double-sandwich enzymelinked immunosorbent assay for detection of human immunoglobulin M anti-Toxoplasma gondii antibodies. J Clin Microbiol. 1986;24:849-50.

63. Obwaller A, Hassl A, Picher O, Aspock H. An enzyme-linked immunosorbent assay with whole trophozoites of Toxoplasma gondii from serum-free tissue culture for detection of specific antibodies. Parasitol Res. 1995;81:361-4.

64. Lau YL, Fong MY, Idris MM, Ching XT. Cloning and expression of Toxoplasma gondii dense granule antigen 2 (GRA2) gene by Pichia pastoris. Southeast Asian J Trop Med Public Health. 2012:43:10-6.

65. Thiruvengadam G, Init I, Fong MY, Lau YL. Optimization of the expression of surface antigen SAG1/2 of Toxoplasma gondii in the yeast Pichia pastoris. Trop Biomed. 2011;28:506-13.

66. Chang PY, Fong MY, Nissapatorn V, Lau YL. Evaluation of Pichia pastorisexpressed recombinant rhoptry protein 2 of Toxoplasma gondii for its application in diagnosis of toxoplasmosis. Am J Trop Med Hyg. 2011:85:485-9.

67. Wang Z, Ge W, Li J, Song M, Sun H, Wei F, et al. Production and evaluation of recombinant granule antigen protein GRA7 for serodiagnosis of Toxoplasma gondii infection in cattle. Foodborne Pathog Dis. 2014:11:734-9.

68. Wang Z, Ge W, Huang SY, Li J, Zhu XQ, Liu Q. Evaluation of recombinant granule antigens GRA1 and GRA7 for serodiagnosis of Toxoplasma gondi infection in dogs. BMC Vet Res. 2014;10:158.

69. Li S, Galvan G, Araujo FG, Suzuki Y, Remington JS, Parmley S. Serodiagnosis of recently acquired Toxoplasma gondii infection using an enzyme-linked immunosorbent assay with a combination of recombinant antigens. Clin Diagn Lab Immun. 2000;7(5):781-7.

70. Aubert D, Maine GT, Villena I, Hunt JC, Howard L, Sheu M, et al. Recombinant antigens to detect Toxoplasma gondii-specific immunoglobulin $\mathrm{G}$ and immunoglobulin $\mathrm{M}$ in human sera by enzyme immunoassay. J Clin Microbiol. 2000;38:1144-50.

71. Pfrepper Kl, Enders G, Gohl M, Krczal D, Hlobil H, Wassenberg D, et al. Seroreactivity to and avidity for recombinant antigens in toxoplasmosis. Clin Diagn Lab Immun. 2005;12:977-82.

72. Hill D, Coss C, Dubey JP, Wroblewski K, Sautter M, Hosten T, et al. Identification of a sporozoite-specific antigen from Toxoplasma gondii. J Parasitol. 2011;97:328-37.

73. Suzuki Y, Ramirez R, Press C, Li S, Parmley S, Thulliez P, et al. Detection of immunoglobulin M antibodies to P35 antigen of Toxoplasma gondii for serodiagnosis of recently acquired infection in pregnant women. J Clin Microbiol. 2000;38:3967-70

74. Lu B, Wu S, Shi Y, Zhang R, Zou L, Gao S, et al. Toxoplasma gondii: expression pattern and detection of infection using full-length recombinant P35 antigen. Exp Parasitol. 2006;113:83-90.
75. Dautu G, Ueno A, Miranda A, Mwanyumba S, Munyaka B, Carmen G, et al. Toxoplasma gondii: detection of MIC10 antigen in sera of experimentally infected mice. Exp Parasitol. 2008;118:362-71.

76. Pappas MG, Lunde MN, Hajkowski R, McMahon J. Determination of IgM and IgG antibodies to Toxoplasma using the IFA test, ELISA, and Dot-ELISA procedures. Vet Parasitol. 1986;20:31-42.

77. Jafar Pour Azami S, Keshavarz H, Rezaian M, Mohebali M, Shojaee S. Rapid detection of Toxoplasma gondii antigen in experimentally infected mice by Dot- ELISA. Iran J Parasitol. 2011;6:28-33.

78. Youssef MM, el-Ganayni GA, el-Shazly AM. The efficacy of IHAT, IFAT and Dot-ELISA in serodiagnosis of toxoplasmosis in complicated pregnancies. J Egypt Soc Parasitol. 1992;22:343-7.

79. Desmonts $G$, Naot Y, Remington JS. Immunoglobulin M-immunosorbent agglutination assay for diagnosis of infectious diseases: diagnosis of acute congenital and acquired Toxoplasma infections. J Clin Microbiol. 1981;14:486-91.

80. Remington JS, Eimstad WM, Araujo FG. Detection of immunoglobulin M antibodies with antigen-tagged latex particles in an immunosorbent assay. J Clin Microbiol. 1983;17:939-41.

81. Thobhani S, Attree S, Boyd R, Kumarswami N, Noble J, Szymanski M, et al. Bioconjugation and characterisation of gold colloid-labelled proteins. J Immunol Methods. 2010;356:60-9.

82. Goni P, Martin B, Villacampa M, Garcia A, Seral C, Castillo FJ, et al. Evaluation of an immunochromatographic dip strip test for simultaneous detection of Cryptosporidium spp, Giardia duodenalis, and Entamoeba histolytica antigens in human faecal samples. Eur J Clin Microbiol. 2012;31:2077-82.

83. Wang YH, Li XR, Wang GX, Yin H, Cai XP, Fu BQ, et al. Development of an immunochromatographic strip for the rapid detection of Toxoplasma gondii circulating antigens. Parasitol Int. 2011;60:105-7.

84. Huang X, Xuan X, Hirata H, Yokoyama N, Xu L, Suzuki N, et al. Rapid immunochromatographic test using recombinant SAG2 for detection of antibodies against Toxoplasma gondii in cats. J Clin Microbiol. 2004; $42: 351-3$

85. Terkawi MA, Kameyama K, Rasul NH, Xuan X, Nishikawa Y. Development of an immunochromatographic assay based on dense granule protein $7 \mathrm{for}$ serological detection of Toxoplasma gondii infection. Clin Vacc Immunol. 2013;20:596-601

86. Suleiman AA, Guilbault GG. Recent developments in piezoelectric immunosensors: a review. Analyst. 1994;119:2279-82.

87. Cabral-Miranda G, de Jesus JR, Oliveira PR, Britto GS, Pontes-de-Carvalho LC, Dutra RF, et al. Detection of parasite antigens in Leishmania infantum-infected spleen tissue by monoclonal antibody-, piezoelectric-based immunosensors. J Parasitol. 2014:100:73-8.

88. Wang $\mathrm{S}$, Yin $\mathrm{T}$, Zeng $\mathrm{S}$, Che $\mathrm{H}$, Yang $\mathrm{F}$, Chen $\mathrm{X}$, et al. A piezoelectric immunosensor using hybrid self-assembled monolayers for detection of Schistosoma japonicum. PLoS One. 2012;7:e30779.

89. Xu S, Mutharasan R. Rapid and sensitive detection of Giardia lamblia using a piezoelectric cantilever biosensor in finished and source waters. Environ Sci Technol. 2010;44:1736-41.

90. Wang H, Lei C, Li J, Wu Z, Shen G, Yu R. A piezoelectric immunoagglutination assay for Toxoplasma gondii antibodies using gold nanoparticles. Biosens Bioelectron. 2004;19:701-9.

91. Stroehle A, Schmid K, Heinzer I, Naguleswaran A, Hemphill A. Performance of a Western immunoblot assay to detect specific anti-Toxoplasma gondii IgG antibodies in human saliva. J Parasitol. 2005;91:561-3.

92. Villard O, Filisetti D, Roch-Deries F, Garweg J, Flament J, Candolfi E. Comparison of enzyme-linked immunosorbent assay, immunoblotting, and PCR for diagnosis of toxoplasmic chorioretinitis. J Clin Microbiol. 2003:41:3537-41.

93. Robert-Gangneux F, Commerce V, Tourte-Schaefer C, Dupouy-Camet J. Performance of a Western blot assay to compare mother and newborn anti-Toxoplasma antibodies for the early neonatal diagnosis of congenital toxoplasmosis. Eur J Clin Microbiol. 1999;18:648-54.

94. Bobic B, Sibalic D, Djurkovic-Djakovic O. High levels of lgM antibodies specific for Toxoplasma gondii in pregnancy 12 years after primary Toxoplasma infection. Case report. Gynecol Obstet Investig. 1991;31(3):182-4.

95. Gorgievski-Hrisoho M, Germann D, Matter L. Diagnostic implications of kinetics of immunoglobulin $\mathrm{M}$ and $\mathrm{A}$ antibody responses to Toxoplasma gondii. J Clin Microbiol. 1996;34:1506-11.

96. Meek B, Diepersloot RJ, van Gool T, Speijer D, Peek R. IgM recognition of recombinant Toxoplasma gondii antigens by sera of acutely or latently infected humans. Diagn Microbiol Infect Dis. 2003;45:45-52. 
97. Gutierrez J, Rodriguez M, Piedrola G, del Carmen MM. Detection of IgA and low-avidity lgG antibodies for the diagnosis of recent active toxoplasmosis. Clin Microbiol Infect. 1997;3:658-62.

98. Hedman K, Lappalainen M, Seppaia I, Makela O. Recent primary Toxoplasma infection indicated by a low avidity of specific lgG. J Infect Dis. 1989;159:736-40

99. de Ory F, Casas I, Domingo CJ, Echevarria J. Application of fluoroimmunoassay to the identification of low avidity specific lgG against pathogenic human viruses and Toxoplasma gondii. Clin Diagn Virol. 1995:3:323-32

100. Ashburn D, Joss AW, Pennington TH, Ho-Yen DO. Do IgA, lgE, and lgG avidity tests have any value in the diagnosis of Toxoplasma infection in pregnancy? J Clin Pathol. 1998;51:312-5.

101. Ali-Heydari S, Keshavarz H, Shojaee S, Mohebali M. Diagnosis of antigenic markers of acute toxoplasmosis by lgG avidity immunoblotting. Parasite. 2013;20:18.

102. Deshpande PS, Kotresha D, Noordin R, Yunus MH, Saadatnia G, Golkar M, et al. IgG avidity Western blot using Toxoplasma gondii rGRA-7 cloned from nucleotides 39-711 for serodiagnosis of acute toxoplasmosis. Rev Inst Med Trop Sao Paulo. 2013;55:79-83.

103. Rossi CL. A simple, rapid enzyme-linked immunosorbent assay for evaluating immunoglobin $\mathrm{G}$ antibody avidity in toxoplasmosis. Diagn Microbiol Infect Dis. 1998:30:25-30.

104. Cozon GJ, Ferrandiz J, Nebhi H, Wallon M, Peyron F. Estimation of the avidity of immunoglobulin $\mathrm{G}$ for routine diagnosis of chronic Toxoplasma gondii infection in pregnant women. Eur J Clin Microbiol. 1998;17:32-6.

105. Buffolano W, Lappalainen M, Hedman L, Ciccimarra F, Del Pezzo M, Rescaldani $R$, et al. Delayed maturation of lgG avidity in congenital toxoplasmosis. Eur J Clin Microbiol. 2004;23:825-30.

106. Meroni V, Genco F, Tinelli C, Lanzarini P, Bollani L, Stronati M, et al. Spiramycin treatment of Toxoplasma gondii infection in pregnant women impairs the production and the avidity maturation of $T$. gondii-specific immunoglobulin G antibodies. Clin Vacc Immunol. 2009;16:1517-20.

107. Lefevre-Pettazzoni M, Bissery A, Wallon M, Cozon G, Peyron F, Rabilloud M. Impact of spiramycin treatment and gestational age on maturation of Toxoplasma gondii immunoglobulin G avidity in pregnant women. Clin Vacc Immunol. 2007;14:239-43.

108. Lefevre-Pettazzoni M, Le Cam S, Wallon M, Peyron F. Delayed maturation of immunoglobulin $\mathrm{G}$ avidity: implication for the diagnosis of toxoplasmosis in pregnant women. Eur J Clin Microbiol. 2006;25(11):687-93.

109. Bonyadi MR, Bastani P. Modification and evaluation of avidity lgG testing for differentiating of Toxoplasma gondii infection in early stage of pregnancy. Cell J. 2013;15:238-43.

110. Virkola K, Lappalainen M, Valanne L, Koskiniemi M. Radiological signs in newborns exposed to primary Toxoplasma infection in utero. Pediatr Radiol. 1997;27:133-8.

111. Blaakaer J. Ultrasonic diagnosis of fetal ascites and toxoplasmosis. Acta Obst Gyn Scan. 1986;65:653-4

112. Vutova K, Peicheva Z, Popova A, Markova V, Mincheva N, Todorov T. Congenital toxoplasmosis: eye manifestations in infants and children. Ann Trop Paediatr. 2002;22:213-8.

113. Porter SB, Sande MA. Toxoplasmosis of the central nervous system in the acquired immunodeficiency syndrome. New Engl J Med. 1992;327:1643-8.

114. Alenghat JP, Morris JH, Kido DK, Rumbaugh CL. Computed tomography in opportunistic cerebral toxoplasmosis: report of two cases. Comput Tomogr 1981:5:231-7.

115. Collins AT, Cromwell LD. Computed tomography in the evaluation of congenital cerebral toxoplasmosis. J Comput Assist Tomo. 1980;4(3):326-9.

116. Foulon W, Naessens A, Mahler T, de Waele M, de Catte L, de Meuter F. Prenatal diagnosis of congenital toxoplasmosis. Obstet Gynecol. 1990;76:769-72.

117. Abboud P, Harika G, Saniez D, Gabriel R, Bednarczyk L, Chemla C, et al. Ultrasonic signs of fetal toxoplasmosis. Review of the literature. J Gynecol Obstet Biol Reprod. 1995;24:733-8.

118. Saiki RK, Gelfand DH, Stoffel S, Scharf SJ, Higuchi R, Horn GT, et al. Primerdirected enzymatic amplification of DNA with a thermostable DNA polymerase. Science. 1988;239:487-91.

119. Burg JL, Grover CM, Pouletty P, Boothroyd JC. Direct and sensitive detection of a pathogenic protozoan, Toxoplasma gondii, by polymerase chain reaction. J Clin Microbiol. 1989;27:1787-92.
120. Khalifa K-S, Roth A, Roth B, Arasteh KN, Janitschke K. Value of PCR for evaluating occurrence of parasitemia in immunocompromised patients with cerebral and extracerebral toxoplasmosis. J Clin Microbiol. 1994;32:2813-9.

121. Hohlfeld P, Daffos F, Costa JM, Thulliez P, Forestier F, Vidaud M. Prenatal diagnosis of congenital toxoplasmosis with a polymerase-chain-reaction test on amniotic fluid. New Engl J Med. 1994;331:695-9.

122. Parmley SF, Goebel FD, Remington JS. Detection of Toxoplasma gondii in cerebrospinal fluid from AIDS patients by polymerase chain reaction. J Clin Microbiol. 1992;30:3000-2.

123. Ho-Yen DO, Joss AW, Balfour AH, Smyth ET, Baird D, Chatterton JM. Use of the polymerase chain reaction to detect Toxoplasma gondii in human blood samples. J Clin Pathol. 1992;45:910-3.

124. Lamoril J, Molina JM, de Gouvello A, Garin YJ, Deybach JC, Modai J, et al. Detection by PCR of Toxoplasma gondii in blood in the diagnosis of cerebral toxoplasmosis in patients with AIDS. J Clin Pathol. 1996;49:89-92.

125. Homan WL, Vercammen M, De Braekeleer J, Verschueren $H$. Identification of a 200- to 300-fold repetitive 529 bp DNA fragment in Toxoplasma gondii, and its use for diagnostic and quantitative PCR. Int J Parasitol. 2000:30:69-75.

126. Reischl U, Bretagne S, Kruger D, Ernault P, Costa JM. Comparison of two DNA targets for the diagnosis of Toxoplasmosis by real-time PCR using fluorescence resonance energy transfer hybridization probes. BMC Infect Dis. 2003;3:7.

127. Hurtado A, Aduriz G, Moreno B, Barandika J, Garcia-Perez AL. Single tube nested PCR for the detection of Toxoplasma gondii in fetal tissues from naturally aborted ewes. Vet Parasitol. 2001;102:17-27.

128. Jauregui LH, Higgins J, Zarlenga D, Dubey JP, Lunney JK. Development of a real-time PCR assay for detection of Toxoplasma gondii in pig and mouse tissues. J Clin Microbiol. 2001;39:2065-71.

129. Calderaro A, Piccolo G, Gorrini C, Peruzzi S, Zerbini L, Bommezzadri S, et al. Comparison between two real-time PCR assays and a nested-PCR for the detection of Toxoplasma gondii. Acta Biomed. 2006;77:75-80.

130. Fallahi S, Kazemi B, SJ S t, Bandehpour M, Lasjerdi Z, Taghipour N, et al. Comparison of the RE and B1 gene for detection of Toxoplasma gondi infection in children with cancer. Parasitol Int. 2014;63:37-41.

131. Jones CD, Okhravi N, Adamson P, Tasker S, Lightman S. Comparison of PCR detection methods for B1, P30, and 18S rDNA genes of T. gondii in aqueous humor. Invest Ophth Vis Sci. 2000;41:634-44.

132. Emrich T, Karl G. Nonradioactive detection of telomerase activity using a PCR-ELISA-based telomeric repeat amplification protocol. Methods Mol Biol. 2002;191:147-58

133. Martinez E, Carmelo E, Alonso R, Ortega A, Pinero J, del Castillo A, et al. Development of a rapid polymerase chain reaction-ELISA assay using polystyrene beads for the detection of Toxoplasma gondii DNA. Lett Appl Microbiol. 2003:36:30-4.

134. Kompalic-Cristo A, Frotta C, Suarez-Mutis M, Fernandes O, Britto C. Evaluation of a real-time PCR assay based on the repetitive B1 gene for the detection of Toxoplasma gondii in human peripheral blood. Parasitol Res. 2007;101:619-25.

135. Nogui FL, Mattas S, Turcato Junior G, Lewi DS. Neurotoxoplasmosis diagnosis for HIV-1 patients by real-time PCR of cerebrospinal fluid. Braz J Infect Dis. 2009;13:18-23.

136. Dworkin LL, Gibler TM, Van Gelder RN. Real-time quantitative polymerase chain reaction diagnosis of infectious posterior uveitis. Arch Ophthalmol. 2002:120:1534-9.

137. Kasper DC, Sadeghi K, Prusa AR, Reischer GH, Kratochwill K, Forster-Waldl E, et al. Quantitative real-time polymerase chain reaction for the accurate detection of Toxoplasma gondii in amniotic fluid. Diagn Micr Infect Dis. 2009;63:10-5.

138. Menotti J, Vilela G, Romand S, Garin YJ, Ades L, Gluckman E, et al. Comparison of PCR-enzyme-linked immunosorbent assay and real-time PCR assay for diagnosis of an unusual case of cerebral toxoplasmosis in a stem cell transplant recipient. J Clin Microbiol. 2003;41:5313-6.

139. Teixeira LE, Kanunfre KA, Shimokawa PT, Targa LS, Rodrigues JC, Domingues $W$, et al. The performance of four molecular methods for the laboratory diagnosis of congenital toxoplasmosis in amniotic fluid samples. Rev Soc Bras Med Trol. 2013;46:584-8.

140. Bretagne S, Costa JM. Towards a nucleic acid-based diagnosis in clinical parasitology and mycology. Clin Chim Acta. 2006;363:221-8.

141. Opsteegh M, Langelaar M, Sprong H, den Hartog L, De Craeye S, Bokken G, et al. Direct detection and genotyping of Toxoplasma gondii in meat 
samples using magnetic capture and PCR. Int J Food Microbiol. 2010;139:193-201.

142. Jurankova J, Basso W, Neumayerova H, Balaz V, Janova E, Sidler X, et al. Brain is the predilection site of Toxoplasma gondii in experimentally inoculated pigs as revealed by magnetic capture and real-time PCR. Food Microbiol. 2014;38:167-70.

143. Jurankova J, Opsteegh M, Neumayerova H, Kovarcik K, Frencova A, Balaz V, et al. Quantification of Toxoplasma gondii in tissue samples of experimentally infected goats by magnetic capture and real-time PCR. Vet Parasitol. 2013:193:95-9.

144. Notomi T, Okayama H, Masubuchi H, Yonekawa T, Watanabe K, Amino N, et al. Loop-mediated isothermal amplification of DNA. Nucleic Acids Res. 2000;28:e63.

145. Wang $Y$, Wang $G$, Zhang D, Yin H, Wang M. Detection of acute toxoplasmosis in pigs using loop-mediated isothermal amplification and quantitative PCR. Korean J Parasitol. 2013;51:573-7.

146. Lin Z, Zhang Y, Zhang H, Zhou Y, Cao J, Zhou J. Comparison of loopmediated isothermal amplification (LAMP) and real-time PCR method targeting a 529-bp repeat element for diagnosis of toxoplasmosis. Vet Parasitol. 2012;185:296-300.

147. Lau YL, Meganathan P, Sonaimuthu P, Thiruvengadam G, Nissapatorn V, Chen Y. Specific, sensitive, and rapid diagnosis of active toxoplasmosis by a loop-mediated isothermal amplification method using blood samples from patients. J Clin Microbiol. 2010;48:3698-702.

148. Cao L, Cheng R, Yao L, Yuan S, Yao X. Establishment and application of a loop-mediated isothermal amplification method for simple, specific, sensitive and rapid detection of Toxoplasma gondii. J Vet Med Sci. 2014;76:9-14

149. Zhang H, Thekisoe OM, Aboge GO, Kyan H, Yamagishi J, Inoue N, et al. Toxoplasma gondii: sensitive and rapid detection of infection by loopmediated isothermal amplification (LAMP) method. Exp Parasitol. 2009;122:47-50.

150. Hu X, Pan CW, Li YF, Wang H, Tan F. Urine sample used for detection of Toxoplasma gondii infection by loop-mediated isothermal amplification (LAMP). Folia Parasit. 2012;59:21-6.

151. Sotiriadou I, Karanis P. Evaluation of loop-mediated isothermal amplification for detection of Toxoplasma gondii in water samples and comparative findings by polymerase chain reaction and immunofluorescence test (IFT). Diagn Micr Infec Dis. 2008;62:357-65.

152. Qu D, Zhou H, Han J, Tao S, Zheng B, Chi N, et al. Development of reverse transcription loop-mediated isothermal amplification (RT-LAMP) as a diagnostic tool of Toxoplasma gondii in pork. Vet Parasitol. 2013;192:98-103.

153. Mikita K, Maeda T, Ono T, Miyahira Y, Asai T, Kawana A. The utility of cerebrospinal fluid for the molecular diagnosis of toxoplasmic encephalitis Diagn Micr Infec Dis. 2013;75:155-9.

154. Krasteva D, Toubiana M, Hartati S, Kusumawati A, Dubremetz JF, Widada JS. Development of loop-mediated isothermal amplification (LAMP) as a diagnostic tool of toxoplasmosis. Vet Parasitol. 2009;162:327-31.

155. Gallas-Lindemann C, Sotiriadou I, Mahmoodi MR, Karanis P. Detection of Toxoplasma gondii oocysts in different water resources by loop mediated isothermal amplification (LAMP). Acta Trop. 2013;125:231-6.

156. Ajzenberg D, Collinet F, Mercier A, Vignoles P, Darde ML. Genotyping of Toxoplasma gondii isolates with 15 microsatellite markers in a single multiplex PCR assay. J Clin Microbiol. 2010;48:4641-5.

157. Li M, Mo XW, Wang L, Chen H, Luo QL, Wen HQ, et al. Phylogeny and virulence divergency analyses of Toxoplasma gondii isolates from China. Parasit Vectors. 2014;7:133.

158. Ajzenberg D, Banuls AL, Tibayrenc M, Darde ML. Microsatellite analysis of Toxoplasma gondii shows considerable polymorphism structured into two main clonal groups. Int J Parasitol. 2002;32:27-38.

159. Blackston CR, Dubey JP, Dotson E, Su C, Thulliez P, Sibley D, et al. Highresolution typing of Toxoplasma gondii using microsatellite loci. J Parasitol. 2001;87(6):1472-5.

160. Quan JH, Kim TY, Choi IU, Lee YH. Genotyping of a Korean isolate of Toxoplasma gondii by multilocus PCR-RFLP and microsatellite analysis. Korean J Parasitol. 2008;46:105-8.

161. Dumetre A, Ajzenberg D, Rozette L, Mercier A, Darde ML. Toxoplasma gondii infection in sheep from Haute-Vienne, France: seroprevalence and isolate genotyping by microsatellite analysis. Vet Parasitol. 2006;142:376-9.

162. Khan A, Jordan C, Muccioli C, Vallochi AL, Rizzo LV, Belfort Jr R, et al. Genetic divergence of Toxoplasma gondii strains associated with ocular toxoplasmosis, Brazil. Emerg Infect Dis. 2006;12:942-9.
163. Khan A, Fux B, Su C, Dubey JP, Darde ML, Ajioka JW, et al. Recent transcontinental sweep of Toxoplasma gondii driven by a single monomorphic chromosome. Proc Natl Acad Sci U S A. 2007;104:14872-7.

164. Ajzenberg D, Cogne N, Paris L, Bessieres MH, Thulliez P, Filisetti D, et al. Genotype of 86 Toxoplasma gondii isolates associated with human congenital toxoplasmosis, and correlation with clinical findings. J Infect Dis. 2002;186:684-9.

165. Lehmann T, Marcet PL, Graham DH, Dahl ER, Dubey JP. Globalization and the population structure of Toxoplasma gondii. Proc Natl Acad Sci U S A. 2006;103:11423-8.

166. Khan A, Taylor S, Su C, Mackey AJ, Boyle J, Cole R, et al. Composite genome map and recombination parameters derived from three archetypal lineages of Toxoplasma gondii. Nucleic Acids Res. 2005;33:2980-92.

167. Khan A, Su C, German M, Storch GA, Clifford DB, Sibley LD. Genotyping of Toxoplasma gondii strains from immunocompromised patients reveals high prevalence of type I strains. J Clin Microbiol. 2005;43:5881-7.

168. Su C, Zhang X, Dubey JP. Genotyping of Toxoplasma gondii by multilocus PCR-RFLP markers: a high resolution and simple method for identification of parasites. Int J Parasitol. 2006;36:841-8.

169. Ferreira IM, Vidal JE, Costa-Silva TA, Meira CS, Hiramoto RM, de Oliveira AC P, et al. Toxoplasma gondii: genotyping of strains from Brazilian AIDS patients with cerebral toxoplasmosis by multilocus PCR-RFLP markers. Exp Parasitol. 2008;118:221-7.

170. Dubey JP, Sundar N, Gennari SM, Minervino AH, Farias NA, Ruas JL, et al. Biologic and genetic comparison of Toxoplasma gondii isolates in free-range chickens from the northern Para state and the southern state Rio Grande do Sul, Brazil revealed highly diverse and distinct parasite populations. Vet Parasitol. 2007;143:182-8.

171. Zhou Y, Zhang H, Cao J, Gong H, Zhou J. Isolation and genotyping of Toxoplasma gondii from domestic rabbits in China to reveal the prevalence of type III strains. Vet Parasitol. 2013;193:270-6.

172. Su C, Khan A, Zhou P, Majumdar D, Ajzenberg D, Darde ML, et al. Globally diverse Toxoplasma gondii isolates comprise six major clades originating from a small number of distinct ancestral lineages. Proc Natl Acad Sci U S A. 2012;109:5844-9.

173. Huang SY, Cong W, Zhou P, Zhou DH, Wu SM, Xu MJ, et al. First report of genotyping of Toxoplasma gondii isolates from wild birds in China. J Parasitol. 2012;98:681-2.

174. Zhou P, Sun XT, Yin CC, Yang JF, Yuan ZG, Yan HK, et al. Genetic characterization of Toxoplasma gondii isolates from pigs in southwestern China. J Parasitol. 2011;97:1193-5.

175. Zhou P, Zhang H, Lin RQ, Zhang DL, Song HQ, Su C, et al. Genetic characterization of Toxoplasma gondii isolates from China. Parasitol Int. 2009:58:193-5

176. Dubey JP, Zhu XQ, Sundar N, Zhang H, Kwok OC, Su C. Genetic and biologic characterization of Toxoplasma gondii isolates of cats from China. Vet Parasitol. 2007;145:352-6.

177. Guo ZG, Gross U, Johnson AM. Toxoplasma gondii virulence markers identified by random amplified polymorphic DNA polymerase chain reaction. Parasitol Res. 1997;83:458-63.

178. Guo ZG, Johnson AM. Genetic characterization of Toxoplasma gondii strains by random amplified polymorphic DNA polymerase chain reaction. Parasitology. 1995;111:127-32.

179. Ferreira Ade M, Vitor RW, Carneiro AC, Brandao GP, Melo MN. Genetic variability of Brazilian Toxoplasma gondii strains detected by random amplified polymorphic DNA-polymerase chain reaction (RAPD-PCR) and simple sequence repeat anchored-PCR (SSR-PCR). Infect Genet Evol. 2004:4:131-42.

180. Arif IA, Bakir MA, Khan HA, Al Farhan AH, Al Homaidan AA, Bahkali AH, et al. A brief review of molecular techniques to assess plant diversity. Inter J Mol Sci. 2010;11(5):2079-96.

181. Jex AR, Smith HV, Monis PT, Campbell BE, Gasser RB. Cryptosporidiumbiotechnological advances in the detection, diagnosis and analysis of genetic variation. Biotechnol Adv. 2008;26:304-17.

182. Costa JM, Cabaret O, Moukoury S, Bretagne S. Genotyping of the protozoan pathogen Toxoplasma gondii using high-resolution melting analysis of the repeated B1 gene. J Microbiol Methods. 2011;86:357-63.

183. Costa JM, Alanio A, Moukoury S, Clairet V, Debruyne M, Poveda JD, et al. Direct genotyping of Toxoplasma gondii from amniotic fluids based on B1 gene polymorphism using minisequencing analysis. BMC Infect Dis. 2013;13:552 
184. Kong JT, Grigg ME, Uyetake L, Parmley S, Boothroyd JC. Serotyping of Toxoplasma gondii infections in humans using synthetic peptides. J Infect Dis. 2003;187:1484-95.

185. Xiao J, Buka SL, Cannon TD, Suzuki Y, Viscidi RP, Torrey EF, et al. Serological pattern consistent with infection with type I Toxoplasma gondii in mothers and risk of psychosis among adult offspring. Microbes Infect. 2009;11:1011-8.

186. Sousa S, Ajzenberg D, Marle M, Aubert D, Villena I, da Costa JC, et al. Selection of polymorphic peptides from GRA6 and GRA7 sequences of Toxoplasma gondii strains to be used in serotyping. Clin Vacc Immunol. 2009;16:1158-69

187. Sousa S, Canada N, Correia da Costa JM, Darde ML. Serotyping of naturally Toxoplasma gondii infected meat-producing animals. Vet Parasitol. 2010;169:24-8

188. Sousa S, Ajzenberg D, Vilanova M, Costa J, Darde ML. Use of GRA6derived synthetic polymorphic peptides in an immunoenzymatic assay to serotype Toxoplasma gondii in human serum samples collected from three continents. Clin Vacc Immunol. 2008;15:1380-6.

189. Peyron F, Lobry JR, Musset K, Ferrandiz J, Gomez-Marin JE, Petersen E, et al. Serotyping of Toxoplasma gondii in chronically infected pregnant women: predominance of type II in Europe and types I and III in Colombia (South America). Microbes Infect. 2006;8:2333-40.

190. Maksimov P, Zerweck J, Dubey JP, Pantchev N, Frey CF, Maksimov A, et al. Serotyping of Toxoplasma gondii in cats (Felis domesticus) reveals predominance of type II infections in Germany. PLoS One. 2013;8:e80213.

191. Maksimov P, Zerweck J, Maksimov A, Hotop A, Gross U, Spekker K, et al. Analysis of clonal type-specific antibody reactions in Toxoplasma gondii seropositive humans from Germany by peptide-microarray. PLoS One. 2012; $7:$ :e34212

192. Turunen $H$, Vuorio KA, Leinikki PO. Determination of IgG, IgM and IgA antibody responses in human toxoplasmosis by enzyme-linked immunosorbent assay (ELISA). Scand J Infect Dis. 1983;15:307-11.

193. Li S, Maine G, Suzuki Y, Araujo FG, Galvan G, Remington JS, et al. Serodiagnosis of recently acquired Toxoplasma gondii infection with a recombinant antigen. J Clin Microbiol. 2000;38:179-84.

194. Chandramukhi A. Diagnosis of neurotoxoplasmosis by antibody detection in cerebrospinal (CSF) fluid using latex agglutination test and ELISA. J Commun Dis. 2004;36:153-8.

195. Trees AJ, Crozier SJ, Buxton D, Blewett DA. Serodiagnosis of ovine toxoplasmosis: an assessment of the latex agglutination test and the value of IgM specific titres after experimental oocyst-induced infections. Res Vet Sci. 1989:46:67-72.

196. Rilling V, Dietz K, Krczal D, Knotek F, Enders G. Evaluation of a commercial lgG/lgM Western blot assay for early postnatal diagnosis of congenital toxoplasmosis. Eur J Clin Microbiol. 2003;22:174-80

197. Cresti S, Ciacci C, Donati E, Giordano I, Tordini G, Barberi A. Evaluation of PCR methods for 5S-rDNA and p30 genes to detect Toxoplasma gondii in blood and other clinical samples. New Microbiol. 2001;24:171-4.

198. Yu H, Huang B, Zhuo X, Chen X, Du A. Evaluation of a real-time PCR assay based on the single-copy SAG1 gene for the detection of Toxoplasma gondii. Vet Parasitol. 2013;197:670-3.

199. Wahab T, Edvinsson B, Palm D, Lindh J. Comparison of the AF146527 and $B 1$ repeated elements, two real-time PCR targets used for detection of Toxoplasma gondii. J Clin Microbiol. 2010;48:591-2.

200. Kong QM, Lu SH, Tong QB, Lou D, Chen R, Zheng B, et al. Loopmediated isothermal amplification (LAMP): early detection of Toxoplasma gondii infection in mice. Parasite Vector. 2012;5:2.

\section{Submit your next manuscript to BioMed Central and take full advantage of:}

- Convenient online submission

- Thorough peer review

- No space constraints or color figure charges

- Immediate publication on acceptance

- Inclusion in PubMed, CAS, Scopus and Google Scholar

- Research which is freely available for redistribution 